\title{
BERHIJRAH DARI SISTEM EKONOMI SEKULER MENUJU SISTEM EKONOMI SYARI'AH
}

\author{
Oleh: Drs. Dahrun Sajadi, MA
}

A. Abstrak

Islam adalah sebuah sistem kehidupan yang lengkap. Kemampuan Islam dalam menciptakan kemajuan, kesejahteraan, dan kemakmuran telah terbukti di saat sistem Islam diberlakukan dan menjadi super power di seantero dunia. Konsep Islam mengenai ekonomi terbukti lebih unggul dibanding sistem ekonomi manapun. Kemampuan Islam menjawab krisis global dapat ditelusuri dari kenyataan, bisa dilihat dari kenyataan paradigmatis ${ }^{2}$ berikut ini:

Politik ekonomi Islam didasarkan paradigma bahwa negara wajib menjamin tercapainya pemenuhan semua kebutuhan primer (basic needs) tiap warga, serta kemungkinan setiap orang memenuhi kebutuhan pelengkapnya. Pandangan semacam ini menjadi dasar bagi pemerintah dalam melakukan seluruh kegiatan ekonomi dalam negara. Negara tidak diperkenankan menetapkan pajak (dlariibah) bagi rakyatnya, dan tidak ada pandangan bahwa negara perlu atau tidak memberikan subsidi. Sebab, konteks hubungan antara negara dan rakyat dalam pandangan Islam adalah pelayanan dan pengaturan, bukan hubungan bisnis antara bawahan dan atasan. Karena itu, dalam konteks pelayanan dan pengaturan terhadap urusan rakyat, negara wajib memenuhi kepentingan rakyat banyak. Negara bahkan menjamin terpenuhinya kebutuhan primer atau vital tiap orang yang hidup dalam negara Islam, misalnya listrik, kesehatan, pendidikan, keamanan dan lainnya. Negara akan mengukur tingkat kesejahteraan berdasarkan tercukupinya kebutuhan primer dan pelengkap tiap-tiap individu.

\section{B. Ungkapan Masalah}

Munculnya kecenderungan tertentu yang mengancam sistem kehidupan dunia telah disadari secara luas pada dekade 1970-an, setelah diadakan Konferensi Stockholm mengenai Lingkungan Hidup, dengan diterbitkannya A Blueprint for Survival ${ }^{3}$ dari The Ecologist, dan Laporan Pertama untuk Club Rome, The Limits to The Growth. ${ }^{4}$ Hampir semua krisis yang dihadapi dunia berasal dari sejumlah kecenderungan multidimensional yang saling mengikat, di antaranya:

1 Penulis: Dosen Fakultas Agama Islam Universitas Islam As-Syafi'iyah Jakarta.

2 Mohammad Husain 'Abdullah, Dirasaat fi al-Fikr al-Islaamiy, ed. I, 1990, hal. 57-58.

${ }^{3}$ Ziauddin Sardar, The Future of Muslim Civilisaation, terj: Rahmani Astuti, Rekayasa Masa Depan Peradaban Muslim, Bandung: Mizan, h.100; catatan kaki E.Goldsmith, R.Allen et.al., A Blueprint for Survival, The Ecologist, jld. 2 no.1 (Januari 1971); perkiran kembali E. Goldsmith, 'Deindustrialising Society', The Ecologist, jld..7, no.4 (Mei 1977), h. 18 - 43.

${ }^{4}$ Ibid.; D. Meadows et al, The Limits to Growth, Potomac Associates, New York, 1972. 
1. Meningkatnya pengaruh lingkungan terhadap aktivitas manusia dan semakin sedikitnya sumber-sumber yang dapat dilestarikan.

2. Meningkatnya eksponensia penduduk dunia dan masalah-masalah peningkatan produksi pertanian untuk mencukupi kebutuhan pangan.

3. Meningkatnya kecenderungan-kecenderungan pada modernisasi dan industrialisasi dari hampir seluruh aktivitas manusia.

4. Meningkatnya kecenderungan pada urbanisasi dan tumbuh suburnya megapolis; dan melebarnya jurang antara negara-negara berkembang dengan negara-negara sedang berkembang.

5. Meningkatnya kebergantungan pada teknologi dan meningkatnya kecenderungan pada budaya inderawi (yang bersifat empiris duniawi, sekuler, humanistik, pragmatik, utiliter, dan hedonistik).

6. Meningkatnya pengangguran atau kekurangan lapangan kerja dan pembaruan yang dirangsang timbulnya bukan oleh kebutuhan riil melainkan oleh semakin besarnya ketidakseimbangan konsumsi.

7. Meningkatnya keterpisahan serta keterasingan manusia dari alam, manusia lain, bahkan diri sendiri. ${ }^{5}$

Problematika dunia ini terjadi terutama karena ada subsistem dari Dunia Barat, kapitalisme. Pandangan hidup kapitalisme yang kemudian mendominasi dunia, di baliknya terdapat sejarah pemaksaan, pemerasan, penguasaan, dan penjajahan, sebagai tradisi dari agama Yahudi dan Kristen di satu pihak, serta rasionalisme dan saintisme di lain pihak. ${ }^{6}$ Inilah "malapetaka" pertama yang disebut oleh Gilbert Durand dengan "malapetaka metafisika". Disebutkan bahwa kelahiran pandangan hidup Barat bermula dari proses sekulerisasi, yakni pemisahan hal transendental (agama) dari kehidupan realitas (empirik). Pandangan ini menempatkan agama sebagai moral-ethic (etika moral) saja. Akibatnya sekulerisasi menimbulkan peradaban yang permisive (sikap serba boleh), munculnya eksploitasi, penjajahan, pemerasan, penumpukan kekuatan ekonomi pada pihak kapitalis besar, dekadensi moral, serta kemerosotan nilai akhlaq dan budaya. ${ }^{8}$

Malapetaka berikutnya ${ }^{9}$ muncul dalam bentuk obyektivisme dalam gerakan pembaharuan abad ke-16 M, yang berkisar antara Galileo dan Descartes. Gerakan ini semakin mengalienasi

${ }^{5}$ Ziauddin Sardar, op.cit., h.100-102.

${ }^{6}$ Lynn White, "The Historical Roots of Our Ecological Crisis", jld.155 (1967), h.1203; A.T.Von Leeuwen, Christianity in World History, New York: Scribner, 1964.

${ }^{7}$ Gilbert Durand, On the Disfiguration of the Image of Man in the West, Eronos no.8 (1969), h.45-93, (juga Golgonooza Press, Ipswich, 1976). Bandingkan dengan Nabhani, al-Qiyadah al-Islamiyyah dalam Nizham alIslam, Beirut: tpn., 1953.

${ }^{8}$ Ziauddin Sardar, Loc. Cit.

9 Kemunculan rasionalisme, empirisme, telah menempatkan agama terpisah dari kehidupan manusia, dan digambarkan sebagai bentuk aktivitas khayali yang berlebih-lebihan (Antonio T.Boisen), bentuk derivasi dari skizoprenia (Sigmund Freud). Kemunculan rasionalisme dan terutama empirisme telah memunculkan berbagai pandangan hidup, yang mempunyai kecenderungan pada ajaran hedonisme, liberalisme, individualisme, positivisme, dan berbagai ajaran yang mengeksploitasi dan mengagungkan rasionalitas, tanpa menyadari keterbatasan-keterbatasan empirik dari akal. Di antara kekacauan-kekacauan ini dalam budaya Barat diperkenalkan suatu konsep baru yakni otonomi dan dominasi (derivat dari liberalisme dan individualisme), baik dominasi atas manusia lain, atau dominasi atas alam semesta. Karena dibatasi oleh budaya ini, maka agama Kristen berubah dari suatu kosmologi ilmiah menjadi agama yang lalim dan pongah. Umat Kristen menyatakan dirinya memiliki hak, dalam ukuran besar, atas transendensi alam dari 
manusia Barat selangkah dengan melakukan pemisahan yang sakral dari yang profan (sekulerisme). Manusia Barat kini mendapati dirinya telah menjadi suatu epifenomenon. Dengan demikian, gerakan Renaissance telah memberikan semangat baru kepada dunia Barat, yaitu semangat untuk membebaskan diri dari agama. Agama dipandang menciptakan mitologisasi yang membelenggu manusia, sehingga manusia kehilangan "obyektivitasnya". Akibat lanjutnya adalah, manusia kehilangan sikap kritisnya untuk mentelaah realitas kosmologis dan sosiologisnya. Gerakan ini kemudian beranggapan bahwa realitas kosmologis mempunyai kekuatan supranatural yang dapat membelenggu manusia. ${ }^{10}$

Usaha renaissance yang bertumpu kepada pembebasan terhadap agama, telah memberikan implikasi besar kepada manusia modern terutama kepada civilisasi masyarakat Barat yang kemudian juga diadopsi oleh hampir seluruh dunia. Semangat ini telah melahirkan rasionalisme. Sedangkan rasionalisme membawa dampak kepada revolusi terhadap keagamaan. ${ }^{11}$ Sejak kelahiran renaissance, menurut Kuntowijoyo (1994), fenomena kemajuan pada bidang ilmu pengetahuan dan teknologi tidak mungkin dihindari lagi, sebagai akibat semangat rasionalisme. Tapi di sisi lain, manusia telah teralienasi oleh apa yang diproduksinya. ${ }^{12}$ Atau, di dalam sistem kapitalisme manusia tidak lebih menjadi segmen pasar, yakni bahwa kualitas kerja manusia dan bahkan kualitas kemanusian itu sendiri ditentukan oleh pasar. Jika mereka ingin bekerja, maka mereka harus menjual dan menawarkan jasanya kepada pasar. Akhirnya manusia menjadi bulan-bulanan dari kekuatan pasar. Malapetaka kemanusian dalam sistem kapitalis ternyata tidak lebih ringan dari pada malapetaka akibat sistem sosialis-komunis. Dalam sistem sosialis-komunis manusia tidak menjadi elemen pasar tapi menjadi elemen birokrasi. Begitulah bahwa dalam dua sistem itu manusia diposisikan sebagai elemen saja. ${ }^{13}$ Bahkan, manusia yang dahulunya merupakan pusaat dari segala sesuatu kini terpaksa harus diturunkan derajatnya menjadi tak lebih dari bagian mesin, yakni mesin raksasa teknologi. ${ }^{14}$

Dimulailah babak baru bagi peradaban dunia, dengan mengambil isu utama pertumbuhan ekonomi, yang ditandai dengan lahirnya pandangan hidup kapitalis. Kapitalisme telah mendorong adanya upaya-upaya ke arah "modernisasi" di segala bidang kehidupan. Dampak yang perlu dicatat dari akibat modernisasi adalah timbul dua fenomena mencolok, yakni:

1. Terdesaknya peranan agama oleh rasionalitas manusia;

2. Munculnya paham dan proses historis-sosiologis sebagai derivasi dari rasionalisme.

Tuhan. Muncul penjajahan-penjajahan dengan 3G (Gold, Glory, dan Gospel). Agama Kristen berubah menjadi agama yang menetapkan adanya dualisme dalam diri manusia dan alam (tersekulerkan), sekaligus adanya kepercayan baru bahwa Tuhan telah mengizinkan manusia untuk memeras kekayan alam untuk memenuhi kebutuhannya. Bahkan setelah bentuk pemikiran-pemikiran dan bahasa manusia Barat tidak lagi berkiblat pada agama Kristen, dia tetap terbenam dalam pandangan Yahudi-Kristen. [Ibid].

10 Tobroni \& Syamsul Arifin, Islam Pluralisme Budaya dan Politik, Refleksi Teologi Untuk Aksi Dalam Keberagaman dan Pendidikan, Yogyakarta: SIPRESS, cet-1, 1994, h.9; Bandingkan dengan Dr. Waqar Ahmed Husaini, Islamic Environmental Systems Engineering, London: Macmillan Press Ltd, 1980, bab I.

${ }^{11}$ Ibid.

12 Bahkan menurut Kiergard, manusia modern mengalami apa yang disebut dengan angst, yakni menderita kesepian yang sangat mendalam, kesendirian, kebosanan, dan kesia-sian.

${ }^{13}$ Kuntowijoyo, Paradigma Islam, Interpretasi Untuk Aksi, Bandung: Mizan, cet-vi, 1994, h. 161-162.

${ }^{14}$ Ibid, h.159-162. 
Proses modernisasi akan selalu diiringi dengan industrialisasi. ${ }^{15}$ Transformasi industrial mempunyai pengaruh yang amat luas. Gejala-gejala penting dalam masyarakat industri ialah memanjangnya usia rata-rata, kenaikan yang terus-menerus dalam output nasional, perhatian yang besar bahkan obsesi pada produksi dan ekspansi, penciptan lingkungan buatan bagi manusia, tenaga kerja, dan organisasi yang serba besar, spesialisasi, dan rasionalisasi intelektual dan sosial. $^{16}$

Masyarakat kapitalis-industri mempunyai moralitas baru yang menekankan pada rasionalisme ekonomi, pencapaian perorangan, dan kesamaan. Rasionalisme ekonomi mendorong manusia baik secara kolektif maupun perorangan untuk memaksimalkan perolehan dengan cara memanajemen ilmu pengetahuan dan menerapkan sistem sosial engineering pada masyarakat. Dalam masyarakat kapitalis orang dihargai berdasarkan usaha keras, kemampuan perorangan, kemajuan, dan lain-lain, dengan standar kemajuan material. ${ }^{17}$

Pengaruh industrialisasi sebagaimana dinyatakan Peter L. Berger, bahwa kawasan yang sudah terindustrialisasi biasanya merupakan lahan yang sudah tersekulerkan; terbebaskan dari nilai-nilai keagamaan. Sedangkan usaha-usaha dari pihak agama untuk menaklukkan kawasan ini akan selalu dilihat sebagai upaya yang membahayakan kelangsungan tata ekonomi. ${ }^{18}$ Joseph Schumpeter mencirikan kapitalis sebagai suatu proses destruktif kreatif (bersifat destruktif), yakni proses penggantian yang lama dengan yang baru. Inovasi teknologi atau pembagunan yang diarahkan oleh dinamisme para pengusaha merupakan mesin pendorong visi kapitalisme ini. Pembangunan didefinisikan sebagai perubahan ekonomi spontan dalam suatu bangsa, bukan dipaksakan dari luar. Pembangunan sebenarnya tidak lebih sekedar pertumbuhan atau optimalisasi dari apa yang sudah ada. ${ }^{19}$

Dalam perjalanan sejarah bangsa Indonesia, sikap penolakan terhadap kapitalisme dan liberalisme ini bersemi dan berkembang pada diri pemimpin kebangsan karena konsep liberal yang diterapkan Belanda telah menimbulkan apa yang disebut dengan kesengsaraan, serta tidak memberikan kemerdekan, persamaan dan persaudaran sebagaimana yang mereka slogankan. Bahkan yang mereka rasakan adalah sebaliknya, yakni pemerasan buruh, perampasan tanah rakyat, penindasan kemerdekan, dan perkosan dasar-dasar kemanusian. ${ }^{20}$ Sentimen ini juga terlihat pada diri pemimpin Budi Utomo yang menyebut kapitalisme sebagai

15 Tobroni dan Syamsul Arifin, op.cit., h.7-9

16 Raymond Aron, The Industrial Society, Three Essays on Ideology and Development, New York: Fredick A. Prager Publisher, 1967, h.69.

${ }^{17}$ Kuntowijoyo, op.cit., h.174.

18 Peter L. Berger, The Sacred Canopy, Elements of a Sociological of Religion, New York: Garden City Doubleday and Company Inc, 1969, h.132; Kuntowijoyo, loc.cit.

19 Beberapa orang sebenarnya mengidentifikasikan Schumpeter sebagai seorang ekonomi klasik -Marxis- suatu bukti obyektivitasnya. Dia menggunakan suatu bab untuk konsep "destruktif kreatif" dalam Kapitalisme, Sosialisme, dan Demokrasi, sementara teori pembangu nannya diuraikan detail dalam "The Theory of Economic Development" (Diterjemahkan dari bahasa Jerman oleh Radves Opie, Cambridge, M.A, Harvard University Press, Los Angeles, 1980).

${ }^{20}$ Bung Hatta, Kumpulan Pidato, Jakarta: Idayu, 1983, h. 324. 
sebuah tanaman dari negeri asing (een plant van vreemde bodem) yang tidak sesuai dengan iklim Indonesia. Cokroaminoto menyebut sebagai "kapitalisme-kapitalisme murtad". ${ }^{21}$

Di sisi lain teknologi bukan sekedar produk ilmu pengetahuan beserta temuan-temuannya berupa mesin-mesin, pesawat, kapal, dan lain-lain, tapi juga mencakup sistem organisasi, struktur sosial beserta kekuasannya yang terletak padanya. Dengan demikian teknologi adalah entitas hasil penerapan secara sistematik ilmu pengetahuan alam sebagai satu himpunan rasionalistikempirik dari berbagai pendukungnya dengan maksud hendak menguasai dan mengendalikan gejala-gejala yang dihadapinya melalui proses produktif secara ekonomis. Adapun dampak teknologi terhadap ekonomi adalah:

1. Tumbuhnya mekanisme ekonomi baru dengan pola-pola produksi, distribusi dan konsumsinya yang rasional.

2. Suasana kompetitif berkembang, kehadiran modal asing pada gilirannya menimbulkan rasa keterlibatan masyarakat ke dalam jaringan ekonomi dunia.

3. Pemusatan modal pada kelompok tertentu sebagai implikasi dari keberhasilan mereka yang memenangkan kompetisi (dependensia).

4. Timbul kesenjangan kepemilikan sosial ekonomi.

5. Munculnya monopoli dan dominasi oleh dan dari pemilik modal. ${ }^{22}$

\section{Kronologi Perkembangan Pemikiran Ekonomi}

Di tahun 1776 Barat masih menyebut sistem ekonomi dengan istilah ekonomi politik (political economy) dan bukan disebut sebagai ilmu ekonomi (economics). Political Economy adalah suatu ilmu kemasyarakatan yang membahas hubungan antara proses-proses politik dan ekonomi. ${ }^{23}$ Dalam kamus Inggris dikenal berbegai istilah "international political economy", "global political economy", "political economy of international relations", "politics of global economic relations", dan "international political economics". Sedangkan yang populer, Ekonomi Politik Internasional (EPI) adalah studi mengenai "who gets what kind of values, how much and by what means", yaitu studi yang memusaatkan perhatian pada persoalan distribusi nilai-nilai seperti kekayan, kebutuhan materiil, keamanan dan ketertiban, keadilan, dan kebebasan. ${ }^{24}$ Atau mengenai "distributive justice"25. Didefinisikan oleh Robert A. Isak, EPI sebagai "study of the inequality or asymmetry between nations, and people and the collective learning and positioning patterns that preserve or change this asymmetry". Penulis yang lain merumuskan, EPI adalah the study of the interplay of economics and politics in the world. ${ }^{26}$

${ }^{21}$ Mubyarto, Kemakmuran Rakyat, Kesejahteran Rakyat dan Keadilan Sosial, dalam Dinamika Ekonomi dan Iptek dalam Pembangunan, (Ed.: M Rusli Karim dan Fauzie Ridjal), Yogyakarta: PT. Tiara Wacana Yogya untuk Yayasan Hatta, disponsori oleh Friederich Ebert 'Stiffung --Perwakilan Indonesia, cet. Ke-1, Maret 1992, h.5.

${ }^{22}$ M.T. Arifin, Dampak Teknologi Terhadap Kebudayan, h.114.

${ }^{23}$ Mubyarto, op.cit., h. 7

24 Susan Strange, "Structure, Values, and Risk in the Study of the International Political Economy", dalam R.J. Barry Jones, Respectives on Political Economy, London: Francis Pinter,1983, h. 211.

${ }^{25}$ Edward Weisband, (Ed. Poverty Amidst Plenty), World Political Economy and Distributive Justice, Westview: Boulder, CO, 1989.

${ }^{26}$ Jeffry A. Frieden \& David A. Lake, ed., International Political Economy Perspektives on Global Power and Wealth ,New York: ST.Martin's, 1991, h. 1. 
Demikianlah, ekonomi didefinisikan sebagai sistem produksi, distribusi, dan konsumsi kekayan; sedangkan politik sebagai himpunan lembaga dan aturan yang mengatur berbagai interaksi sosial dan ekonomi.

Tidak demikian halnya dengan persoalan pembagian kekayaan. Persoalannya semata-mata menyangkut kelembagaan manusia. Sekali lembaga itu sudah ada manusia, baik secara perorangan maupun bersama-sama, dapat berbuat apa saja sesuai keinginannya. Mereka bisa menempatkannya bagi siapapun yang mereka kehendaki dan dengan kondisi apa saja. ${ }^{27}$ Dengan demikian pembagian kekayan tergantung pada hukum dan kebiasan yang ada dalam masyarakat. Peraturan-peraturan yang menentukannya dibuat oleh bagian masyarakat yang memerintah, dan yang begitu berbeda dari waktu ke waktu dan dari negara yang satu ke negara yang lain, dan mungkin juga akan masih berbeda lagi, apabila kemanusian memang menghendakinya. ${ }^{28}$ Muncul kemudian penolakan terhadap pemikiran Mill dari Karl Mark, yakni dengan terbitnya sebuah makalah berjudul Manifesto Komunis, yang kemudian melatarbelakangi ekonomi sosialis. Pecahlah kemudian paham ekonomi menjadi:

1. Madzhab neoklasik yang sampai sekarang dipelajari orang (termasuk para ekonom Indonesia),

2. Madzhab sosialis, yang diterapkan di negara-negara Eropa Timur dan negara-negara Komunis di Asia Timur.

Setelah madzhab klasik, muncullah madzhab ekonomi neo-klasik yang lebih menekankan pendekatan dan analisa ekonomi mikro. Muncullah perkembangan baru dalam analisa-analisa ekonomi matematis. Penggunan matematika terutama deferensial dan integral untuk mengetahui batas-batas marginal, maka dalam Principles of Economy (1890), Alfred Marshall yang juga seorang ahli matematika merasa perlu mengingatkan batas-batas penggunan matematika. ${ }^{29}$ Manfa'at yang paling penting dari matematika murni bagi pertanyan-pertanyan ekonomi, hanyalah untuk menolong seseorang untuk menulis secara cepat, singkat, dan tepat apa yang dipikirkannya untuk dirinya sendiri, dan untuk memastikan bahwa ia memiliki cukup premis (dasar) bagi kesimpulannya. ${ }^{30}$ Dengan demikian Alfred Marshal menekankan bahwa ilmu ekonomi harus bersifat terapan (praksis). ${ }^{31}$ Menurutnya ilmu ekonomi harus bertujuan untuk kesejahteran seluruh umat manusia. Dengan bukunya Principles of Economics ini Alfred Marshall menjadi Bapak Ekonomi Neoklasik, atau Bapak Teori Ekonomi Mikro.

Setelah madzhab Neoklasik muncullah madzhab modern yang dimunculkan oleh Keynes dengan bukunya The General Theory of Employment, Interest, and Money (1936). Buku ini lahir ketika terjadi depresi dunia pada tahun 1929. Keynes beranggapan bahwa terjadinya krisis dunia pada tahun 1929-1933 membuktikkan bahwa teori ekonomi klasik dan neoklasik terbukti mempunyai kelemahan mendasar. Pengangguran besar-besaran tetap terjadi selama kurun waktu yang cukup lama, padahal menurut teori ekonomi klasik dan neoklasik tidak mungkin terjadi pengangguran besar-besaran. Pendapat Keynes yang paling mencengangkan adalah bahwa

\footnotetext{
${ }^{27}$ John Stuart Mill, Principles of Political Economy, With Some of Their Application to Social Philosophy, Fairfield: August M. Kelley Publishers, 1977, h. 200.

${ }^{28}$ Ibid., h.200.

${ }^{29}$ Mubyarto, op.cit., Jakarta, h. 11.

${ }^{30}$ Ibid., kutipan ini dalam edisi aslinya, Alfred Marsh., Principles of Economics, New York: The MacMillan Company, 1948, h. X.

${ }^{31}$ Ibid., h. 2.
} 
terjadinya depresi dunia besar-besaran ini bukan disebabkan karena kelemahan para praktisi ekonomi, tapi dikarenakan kesalahan dasar dari teori ekonomi yang diterapkan. "Cacat utama perekonomian di mana kita hidup adalah kegagalannya memberikan pekerjan penuh dan pembagian kekayan serta pendapatan yang tidak adil dan arbiter"32. "Saya percaya bahwa memang ada justifikasi sosial dan psikologi bagi ketidakmeratan pendapatan dan kekayan, tetapi tidaklah harus terlalu besar seperti yang kita saksikan dewasa ini". ${ }^{33}$

Di kemudian hari, pemikiran Keynes mampu mempengaruhi para ekonom dunia untuk mengkaji ulang paradigma ekonomi selama ini. Lebih lanjut Keynes menyatakan bahwa ilmu ekonomi lebih merupakan metode, daripada sekadar doktrin, peralatan, pemikiran dan teknik berpikir. Sedangkan madzhab pemikiran terakhir adalah madzhab pemikiran kontemporer. Tokoh dibalik madzhab ini adalah Gunnar Myrdall, seorang ekonom dari Swedia. Buku Myrdall yang paling terkenal adalah, Asian Drama: An Inquiry into Poverty of Nations, dan bertolak belakang dengan Adam Smith --lihat buku Adam Smith yang berjudul; Wealth of Nations : An Inquiry into the Nature and Causes of Wealth Nations-- walaupun dengan menggunakan alat analisa yang sama. Tulisan-tulisan Myrdall memang radikal; sebagai kritik terhadap teori ekonomi ortodok. ${ }^{34}$ Gagasan penting lain dari Myrdall adalah kajian ekonomi harus juga memasukkan faktor-faktor nonekonomi ${ }^{35}$.

\section{Hubungan antara Ekonomi dan Agama}

Mencari hubungan antara ekonomi dan agama pada era modern ini memang terasa sangat aneh. Ini dikarenakan kultur masyarakat modern telah tersekulerisasi -- meminggirkan dan bahkan berupaya untuk melepaskan diri dari mitologi-mitologi agama -- sehingga mengkaitkan antara agama dan kehidupan ekonomi terasa agak ganjil. Tapi Adam Smith, dalam bukunya The Wealth of Nation, telah banyak berbicara tentang agama, gereja, sekte-sekte agama, moral dan etika. ${ }^{36}$ Pada masanya, ilmu ekonomi yang masih disebut sebagai ekonomi politik (political economy) itu merupakan bagian dari filsafat moral (moral philosophy), yaitu nama dari ilmu-ilmu sosial pada waktu itu. ${ }^{37}$

Ilmu ekonomi membahas perilaku manusia (morales) dan berkaitan erat dengan nilai-nilai yang dianut. Thomas Malthus juga berbicara mengenai pengaruh kendala moral dalam pembahasannya mengenai perilaku ekonomi dan kependudukan. Karl Mark dan Engels pun tidak kurang berbicara mengenai agama Kristen dan Yahudi sebagai faktor yang mempengaruhi sikapsikap dan perilaku ekonomi. Karena itu, Max Weber tidak membicarakan sesuatu yang sama sekali baru, ketika ia menerbitkan dua buah artikelnya pada tahun 1904 dan 1905 yang kini dikenal dengan bukunya The Protestant Ethic and The Spirit of Capitalism. ${ }^{38}$

32 J.M. Keynes, The General of The Employment Interest and Money, Tokyo: Maruzen Co. 1957, h. 327.

${ }^{33}$ Ibid.

${ }^{34}$ Myrdal, Against the Stream, Critical Essay on Economics, New York, Vintage Books, 1975, h. 14.

35 Gunnar Myrdall, The Political Element in the Development of Economics Theory, A.Clarton Book, New York, Simon and Schuster, 1969, h.2.

${ }^{36}$ Adam Smith, The Wealth of Nation, New York: The Modern Library, 1937, h.745-746, dan 741-768.

${ }^{37}$ Robert.L.Heilbroner, The Worldly Philosopheres, New York: A.Touchstone Book, 1970.

38 Max Weber, The Protestant Ethic and the Spirit of Capitalism, terjemahan Talcott Parsons, Unwin University Book, London, 1974. Lihat catatan kaki Chapter I No.189. 
Hubungan antara agama dan perilaku ekonomi serta sejarah, menurut Kenneth Boulding, adalah pengaruh agama terhadap ekonomi dan sejarah lebih besar daripada pengaruh agama terhadap pemikiran ekonomi dan sejarah. Agama turut mempengaruhi pengambilan keputusan mengenai jenis komoditi yang diproduksi, terbentuknya institusi dan tentu juga praktek-praktek atau perilaku ekonomi ${ }^{39}$. Dawam Rahardjo berkata bahwa mayoritas ekonom muslim tidak pernah membahas persoalan-persoalan yang rudimenter, seperti, apakah nilai-nilai Islam itu menunjang perkembangan ekonomi atau tidak, sebagaimana yang masih menjadi pertanyan para ahli teori ilmu-ilmu sosial Barat sejak Weber. Sikap yang diambil oleh para pakar muslim adalah berusaha memahami ajaran-ajaran Islam dalam konteks persoalan sekarang dan kemudian memperkirakan pengaruh atau dampak penerapan nilai-nilai Islam tersebut terhadap perkembangan ekonomi, baik dalam perspektif komparatif dengan berbagai pola pertumbuhan ekonomi yang ada maupun dalam rangka mencari pola yang ideal yang dikehendaki. ${ }^{40}$ Tapi Dr. 'Abd al-Rahman al-Malikiy, berbeda dengan Dawam, justru mengkritik dan menolak sama sekali sistem ekonomi ala kapitalisme dan sosialisme, bahkan meletakkan konstruksi mendasar bagi politik ekonomi Islam. ${ }^{41}$ Masalahnya bukan terletak pada kontribusi Islam untuk melengkapi sistem ekonomi kapitalis dengan nilai-nilai normatif Islam, tapi menghadirkan kembali sistem ekonomi Islam. Pandangan ini secara tegas menyatakan bahwa sistem ekonomi Islam memang ada ${ }^{42}$ dan harus ditegakkan oleh umat Islam. Sosialisasinya adalah dengan menjadikan tema-tema penegakan sistem ekonomi syari'ah (Islam) sebagai bagian integral dari materi dakwah.

Signifikansi konstruksi sistem ekonomi Islam tidak hanya ditetapkan berdasarkan muatan etikanya saja, tapi harus diarahkan kepada upaya pembentukan ekonometri dan sistem ekonomi Islam. Akan lebih tepat kalau digunakan pendekatan sistemis, dengan cara mengkalkulasi secara kualitatif maupun kuantitatif sistem ekonomi khas Islam, maka dengan segera etika Islam akan tercakup di dalamnya. Sedangkan pendekatan substantif atau pendekatan adaptif, mempunyai kelemahan, yakni suatu saat akan terbentur pada bentuk-bentuk formal atau empirik khas ekonomi Islam, yang bisa jadi bertentangan secara diameterikal dengan sistem ekonomi selain Islam. Misalnya, Islam melarang apapun bentuk riba, dan penimbunan barang, sedangkan dalam sistem kapitalis kedua hal ini tidak dilarang. Islam juga melarang negara melakukan intervensi terhadap harga dengan dalih proteksi konsumen atau produsen. Islam pun menetapkan kualifikasi terhadap barang-barang yang bernilai ekonomis; misalnya khamr, daging babi, dan jasa-jasa yang bertentangan dengan sistem Islam, sebagai sesuatu yang tidak bernilai ekonomis. ${ }^{43}$

Akibatnya, bila pendekatan adaptif diadopsi, akan timbul kesulitan di dalam memberikan ciri etika dan norma-norma khas Islam. Pendekatan ini justru akan mengeleminir kemurnian dan logika berfikir Islami. Islam harus digali dan dipahami apa adanya baik dari teks maupun konteks

${ }^{39}$ Lihat Religious Perspektive on Economics, dalam Kenneth E.Boulding, Beyond Economics, Essay on Society, Religion and Ethics, The University of Michigan, Ann Arbor, 1970, h. 180-181; Lihat pula Dawam Rahardjo, op.cit., h.27.

${ }^{40}$ Dawam Rahardjo, ibid., h.62.

41 'Abd al-Rahman al-Malikiy, op.cit., h.5-34.

42 Tentang garis-garis besar sistem ekonomi Islam, dapat dirujuk misalnya, Dr. Husain 'Abdullah dalam Dirasaat fi al-Fikr al-Islamiy, loc.cit.

${ }^{43}$ Nabhani, Nizham al-Iqtishodiy, Beirut: tpn., 1953,. Bandingkan 'Abd al-Qaddim Z, Nizham al-Hukm fi al-Islam, bab Mahkamah al-Mazhalim. 
al-Quran dan al-Sunnah, kemudian diaplikasikan dalam kehidupan sehari-hari. Bukan memahami al-Quran dan al-Sunnah untuk dipaksasesuaikan dengan ajaran-ajaran kapitalis, atau hanya menempatkan ajaran Islam sebagai ajaran moral dan etika. Pendekatan ini (adaptif) hanya akan memerankan Islam sebatas 'penambal' kebobrokan sistem kapitalis. ${ }^{44}$ Masalahnya, sistem ekonomi kapitalis lahir dari suatu peradaban yang memiliki semangat untuk menolak dan mengeleminir peran agama dalam kehidupan. Padahal, pada saat yang sama, seorang muslim memiliki tanggungjawab melaksanakan seluruh ajaran agamanya. Barangkali ada baiknya bila kelemahan sistem ekonomi sekuler (kapitalisme dan sosialisme) dikemukakan di sini sebagai berikut:

\section{Sistem Ekonomi Kapitalis}

Kelangkan dan keterbatasan barang dan jasa itu ada pada karakteristik barang dan jasa, sebagai alat pemuas kebutuhan manusia. Kapitalis berpendapat bahwa kebutuhan manusia harus dipenuhi. ${ }^{45}$ Karena itu, harus ada alat-alat (goods) untuk memenuhi kebutuhan itu. Mereka memahami bahwa alat dan barang hanyalah alat pemuas bagi kebutuhan materi saja. Sedangkan jasa adalah alat pemuas bagi kebutuhan yang bisa dirasakan tapi tidak bisa diindera. Barang dan jasa bisa dijadikan sebagai alat pemuas, jika di dalamnya terkandung kegunan (utility). Bagi mereka, keberadan utility sangat tergantung pada pandangan ada atau tidak adanya kegunan tersebut pada suatu barang dan jasa. Mereka mendefinisikan kebutuhan sebagai keinginan. Suatu barang dianggap berguna jika barang tersebut diinginkan oleh khalayak, baik yang bersifat barang primer maupun non primer, dan apakah barang tersebut secara subyektif memberikan kepuasan (saatisfaction) pada sebagian orang atau tidak menurut orang lain. ${ }^{46}$ Karena itu, mereka tidak pernah membahas karakteristik benda atau barang; apakah bermanfa'at atau berbahaya bagi kehidupan manusia. Menurut mereka, khamr, candu adalah benda yang memiliki utility, sebab benda-benda tersebut masih diinginkan oleh orang banyak. Pelacuran laki dan perempuan; merupakan jasa yang mempunyai utility, sehingga sah-sah saja jasa semacam ini. Ekonom kapitalis tidak pernah membahas topik semacam ini dalam membangun sistem perekonomian mereka. Mereka disibukkan dengan pembahasan bagaimana cara memenuhi kebutuhan manusia, meningkatkan alat-alat pemuas secara kualitas maupun kuantitas dalam rangka memenuhi kebutuhan manusia.

\section{Sistem Ekonomi Sosialis}

Garis-garis besar sistem ekonomi sosialis, dan kritik terhadap sistem ekonomi tersebut dipaparkan cukup gamblang oleh Dr. Abd al-Rahman al-Malikiy dan Nabhani di dalam bukunya yang berjudul, Siyasaat al-Iqtishad al-Mitsla", dan "al-Nidzam al-Iqtishad fi al-

44 Bandingkan Husain 'Abdullah, Mafahim Islam, juz I dan II.

45 Menurut Dr. Husein Abdullah, dalam bukunya Mafahim Islam, Dar al-Bayariq, bahwa manusia mempunyai potensi hidup berupa pertama, kebutuhan materi (hajat al-'udlwiyyah),kedua, kebutuhan akan naluri (gharizah). Kebutuhan jasmani merupakan kebutuhan mutlak dan harus dipenuhi oleh manusia. Sifat pemenuhannya pasti, sehingga apabila tidak dipenuhi maka dapat mengganggu eksistensi manusia tersebut -mengakibatkan kematian atau kerusakan jasmaninya. Sedangkan kebutuhan naluriah (gharizah) sifat pemenuhannya tidak pasti, dalam arti seandainya manusia tidak memenuhinya tidak akan mengganggu eksistensi manusia tersebut, hanya saja menimbulkan kegoncangan jiwa manusia. Dengan demikian, ada kebutuhan-kebutuhan yang tidak pasti pemenuhannya, yakni kebutuhan naluriah.

${ }^{46}$ Qadli Nabhani, Al-Nizham al-Islamiy fi al-Islam, 1990, h.33. 
Islam". 47 Secara umum, sistem ekonomi sosialis memiliki konsep dasar: Mewujudkan kesamaan (equality) secara riil, menghapus kepemilikan individu (private property), baik secara keseluruhan maupun sebagian, serta mengatur produksi dan distribusi secara kolektif. ${ }^{48}$

a. Dari sisi pewujudan kesamaan secara riil, terdapat perbedaan pendapat di aliran sosialisme:

1). Kelompok/Aliran Hisabiyyah, berpendapat bahwa, setiap individu akan diberi sesuatu yang sama, sebagaimana yang lain.

2). Kelompok/Aliran Syuyu'iyah, berpendapat bahwa pembagian kerja harus berdasarkan kemampuan setiap orang, dan pembagian produksi berdasarkan kebutuhan individu. ${ }^{49}$

3). Kelompok/aliran yang memiliki kesamaan dalam alat-alat produksi, berpendapat bahwa benda (materi) tidak cukup untuk memenuhi kebutuhan setiap individu, sehingga mutlak mengikuti kaedah distribusi, masing-masing sesuai kekuatan/kemampuannya, dan masing-masing mendapat bagian sesuai kerja/aktivitasnya. ${ }^{50}$

b. Dari aspek penghapusan kepemilikan individu (private property) mereka berbeda pendapat:

1). Sosialis Komunis, berpendapat: kepemilikan individu harus dihapus secara total.

2). Sosialis Kapitalis, berpendapat: kepemilikan individu yang harus dihapus adalah yang berhubungan dengan barang produktif atau modal (capital). Mereka menghapus kepemilikan individu pada barang yang dapat menghasilkan faktor produksi, misalnya tanah, rel, industri, pertambangan, rumah yang disewakan, pabrik, dll., bukan barang konsumtif atau rumah tempat tinggal.

3). Sosialis-Pertanian, berpendapat: kepemilikan individu yang harus dihapus hanya mengenai tanah pertanian, tidak lebih dari itu.

4). Sosialis Negara, berpendapat: kepemilikan individu yang dihapus adalah setiap hal yang di dalamnya terdapat kepentingan umum. ${ }^{51}$

c. Dari sisi penentuan sarana yang digunakan sebagai alat untuk mewujudkan tujuan-tujuan:

1). Aliran Naqabiyah Tsauriyyah ${ }^{52}$. Aliran ini beranggapan bahwa kebebasan para pekerja dan tenaga kerja merupakan alat untuk mewujudkan masyarakat komunis, misalnya dengan cara memperbanyak kerja, merusak alat produksi, serta menyebarkan etos kerja di kalangan pekerja dan persiapan-persiapan lainnya, sampai pada suatu titik perekonomian terhenti sama sekali, sehingga runtuhlah sistem ekonomi kapitalis.

2). Aliran Sosialis Marxisme, berpendapat bahwa hukum evolusi sosial sudah cukup untuk menghancurkan sistem ekonomi yang ada.

3). Aliran Sosialis Negara, berpendapat bahwa undang-undang-lah sebagai cara untuk menerapkan pemikiran-pemikiran dan sistem sosialisme. Mereka berasumsi bahwa

47 Ibid. h.40-56

48 Qadli Nabhani, Nizham al-Iqtishadiy fi al-Islam (Sistem Ekonomi Dalam Islam), ed. IV, 1990, Beirut: Dar alUmmah, h.42.

${ }^{49}$ Ibid., Aliran ini mendasarkan pembagian ini dengan suatu kaedah, "Setiap orang (akan diberi pekerjan) sesuai dengan kekuatan dan kemampuannya, dan masing-masing akan mendapatkan sesuatu sesuai dengan tingkat kebutuhan masing-masing. Lihat pula karangan 'Abd al-Rahman al-Malikiy, al-Siyasaat al-Iqtishadiyyah al-Mitsla, 1963,tanpa penerbit, h. 21-22.

50 Ibid. h. 42 .

51 Ibid. h. 43.

52 Ibid. 
dengan adanya undang-undang itu maka akan terjaga kemashlahatan umum serta perbaikan kondisi pekerja. ${ }^{53}$

d. Dari segi institusi yang akan mengendalikan proyek-proyek dalam sistem sosialisme,

1). Sosialis Kapitalis berpendapat bahwa pengendalian proyek -- produksi dan distribusi -diserahkan kepada negara.

2). Aliran Naqabiyyah berpendapat bahwa pengendalian distribusi diserahkan kepada sekelompok pekerja yang terorganisir di bawah komando pemimpin-pemimpin mereka. ${ }^{54}$

Teori Karl Mark sangat berpengaruh, ialah teori mengenai nilai (value). Walaupun sebenarnya teori tentang nilai yang dikemukakan Mark diambil dari pemikir Kapitalis, tapi kecerdikan Mark adalah ia menggunakan teori nilai tersebut untuk menyerang konsep ekonomi kapitalis. Adam Smith --bapak ekonomi Kapitalis- mendefiniskan nilai sebagai berikut: "Nilai barang apapun tergantung pada tenaga yang dicurahkan untuk menghasilkan barang tersebut. Karena itu, nilai barang yang proses produksinya menghabiskan waktu dua jam tentu melebihi nilai barang yang produksinya membutuhkan waktu satu jam".55 Kemudian Richardo, mencoba menjelaskan teori usaha tersebut, dan ia mendefinisikan nilai sebagai berikut: "Yang menentukan nilai barang tersebut bukan semata-mata kadar usaha yang secara langsung dikorbankan untuk menghasilkannya, tetapi juga pada usaha yang telah dikorbankan sebelumnya untuk menghasilkan alat-alat dan perlengkapan-perlengkapan yang digunakan dalam proses produksi". 56

Dalam Manifesto Partai Komunis, Karl Marx dan Friedrich Engels (1848), menyebutkan pada bab I. Kaum Borjuis dan Kaum Proletar, "Sejarah dari semua masyarakat ${ }^{57}$ : yang ada hingga sekarang ini adalah sejarah perjuangan kelas. Orang-merdeka dan budak, patrisir dan plebejer $^{58}$, tuan bangsawan dan hamba, tukang-ahli ${ }^{59}$ dan tukang pembantu, pendeknya: penindas dan yang tertindas, senantiasa ada dalam pertentangan satu dengan yang lain, melakukan perjuangan yang tiada putus-putusnya, kadang-kadang dengan tersembunyi, kadang-kadang dengan terang-terangan, suatu perjuangan yang setiap kali berakhir dengan penyusunan-kembali masyarakat umumnya atau dengan sama-sama binasanya kelas-kelas yang bermusuhan.... Masyarakat borjuis modern yang timbul dari runtuhan masyarakat feodal tidak menghilangkan pertentangan-pertentangan kelas. Ia hanya menciptakan kelas-kelas baru,

53 Ibid.

54 Ibid.

55 Nabhani, Nizham al-Iqtishadiy fi al-Islam, Beirut: Dar al-Ummah, ed. iv, 1990, h. 44.

56 Ibid, h. 44.

57 Yang dimaksud dengan borjuasi adalah klas kaum Kapitalis modern, pemilik alat-alat produksi sosial dan pemakai kerja upahan. Dengan proletariat dimaksudkan klas kaum pekerja-upahan modern yang - karena tidak mempunyai alat-alat produksi sendiri - terpaksa menjual tenaga kerja mereka untuk dapat hidup (Keterangan Engels pada edisi Inggris tahun 1888).

58 Kaum patrisir dan plebejer adalah klas-klas di Roma Kuno. Kaum patrisir adalah klas pemilik tanah besar yang berkuasa, yang menguasai tanah dan negara. Kaum plebeyer (dari perkatan pleb - rakjat jelata) adalah klas wargakota yang merdeka, tapi tidak mempunyai hak penuh sebagai wargakota. Untuk mengetahui klas-klas di Roma hingga soal yang sekecil-kecilnya lihatlah buku Engels, Asal-usul Keluarga, Hak Milik Perseorangan dan Negara.

59 Tukang-ahli, yaitu seorang anggota penuh dari suata gilde, seorang ahli di dalam gilde, tapi bukan kepala gilde.(Keterangan Engels pada edisi Inggris tahun 1888). 
syarat-syarat penindasan baru, bentuk-bentuk perjuangan baru sebagai ganti yang lampau.. ${ }^{60}$. Marx berasumsi bahwa perubahan masyarakat kapitalis menunju masyarakat sosialis (komunis), akan berjalan mengikuti hukum dialektika --(materialisme historis), tanpa ada intervensi dari manapun.

Dengan demikian dalam mengubah masyarakat, Marx mempercayakan penuh kepada materialisme historis. Secara ringkas pandangan Mark dapat diringkas sebagai berikut, " Sistem masyarakat apapun, sebenarnya akibat dari suatu kondisi ekonomi, dimana satu-satunya sebab perubahan-perubahan tersebut dikembalikan pada satu hal, yakni perjuangan kelas (classes struggle). Tujuan dari classes struggle ini adalah memperbaiki kondisi ekonomi. Sejarah telah menunjukkan bahwa kelas yang tertindas, atau kelas yang lebih dominan jumlahnya akan terus berjuang, yang di akhirnya akan dimenangkan oleh kelompok tertindas, dan dominan tersebut. Inilah yang disebut dengan teori evolusi sosial. ${ }^{61}$

Tahap akhir dari perjuangan kelas menunjukkan bahwa kelas yang dominan jumlahnya (yakni kaum tertindas) akan menang. Tapi kelompok yang menang ini pada perkembangan berikutnya akan menjadi penindas-penindas baru. Pergerakan ini mengikuti hukum dialektika, dimana negasi lama akan menjadi sinthesa baru, kemudian dicarikan antithesanya, kemudian dari proses dialektika muncul negasi baru, akibat kontradiksi intern. ${ }^{62}$

Tapi sejak revolusi Perancis, perjuangan kelas telah berubah. Yakni perjuangan antara kelas menengah (borjuis) dengan kelas para pekerja (proletar), dimana yang menang akan menjadi pengendali atas proyek-proyek perekonomian dan menjadi pemilik modal atau menjadi kelompok konservatif. Dengan cara inilah kelas proletar bangkit melawan kelas borjuis, dimana menurut Marx, konfrontasi ini dikembalikan pada satu sebab, yakni faktor ekonomi ${ }^{63}$.

Karl Marx berasumsi bahwa perjuangan kelas akan terus terjadi sampai sistem kepemilikan sama dengan sistem produksi. Atau dengan sederhana, sampai kepemilikan menjadi kepemilikan kolektif. Perjuangan kelas ini akan dimenangkan oleh kaum proletar, dengan mengikuti hukum evolusi sosial. ${ }^{64}$

Berakhirnya kelas borjuis oleh kelas pekerja (proletar), dijelaskan dengan teori akumulasi modal (law of capital accumulation). ${ }^{65}$ Teori ini secara ringkas menjelaskan

60 Karl Marx dan Friedrich Engels (1848), Manifesto Partai Komunis, Jakarta: Yayasan Pembaruan, Cet.3, 1959.

61 Ibid.; lihat pula Nabhani, Nizham al-Iqtishad fi al-Islam, h. 45.

62 Untuk lebih jelasnya mengenai hukum evolusi sosial, baca Manifesto Partai Komunis, Karl Marx dan F. Engels, pada bab I. Kaum Borjuis dan Kaum Proletar, dan lihat pula bab II, Kaum Proletar dengan Kaum Komunis.

63 Ibid. Lihat pula Nabhani, al-Nizham al-Iqtishadiy fi al-Islam, ed.iv, 1990, Beirut: Dar al-Ummah, h.45-57.

64 Lihat, Teori Marx, tentang Materialisme Historis, yang menjelaskan perubahan-perubahan sistem masyarakat akibat ekonomi. Pada dialektika sejarah Marx menempatkan keadan ekonomi sebagai "materi". Sehingga dialektika sejarah, sering juga disebut dengan "analisa ekonomis terhadap sejarah" (economic interpretation of history). Dengan hukum dialektis, masyarakat berkembang dari satu kondisi, yakni masyarakat feodal, menuju masyarakat dengan kondisi yang lebih maju (masyarakat kapitalis kemudian menuju sosialis).

65 Sebenarnya teori Law of Capital Accumulation, yang diajarkan oleh Marx diadopsi dari konsep ekonomi Kapitalis. Yakni, terjadinya penggabungan pergerakan modal dan kerja dari berbagai industri atau pabrik. Proses ini terjadi ketika ada sebagian pabrik yang sudah besar (kapitalis raksasa), ada sebagian pabrik yang masih kecil. Fenomena tidak berimbang ini --karena ada persaingan bebas-- akan mengakibatkan jumlah pabrik yang sama produksinya akan berkurang karena telah terjadi sentralisasi produksi. Katakanlah bila dalam satu daerah dahulu terdapat 10 pabrik, maka 
berkurangnya jumlah pemilik modal, dan terus bertambahnya jumlah pekerja. Ini bisa terjadi ketika terjadi apa yang disebut dengan akumulasi modal pada sejumlah pabrik. Ketika itu terjadi persaingan bebas, yang berakibat produk yang dihasilkan akan berlimpah, sehingga kuantitas produk akan melampui jumlah konsumen dari kalangan pekerja disebabkan upah mereka yang tidak mencukupi. Peristiwa ini diklaim oleh Marx sebagai penyebab terjadinya krisis ekonomi, yang akan berdampak habisnya kekayan pada sebagian pemilik modal. Akibatnya pemilik modal yang kehabisan modalnya akan masuk ke dalam kelas pekerja. Krisis inilah sebagai pintu gerbang menuju masyarakat sosialis. Masyarakat sosialis adalah rantai terakhir dari proses dialektika sejarah (evolusi sejarah).

\section{E. Sistem Ekonomi Perspektif Islam}

Ada empat pendekatan yang dianut oleh pakar muslim dalam mengembangkan ekonomi Islam.

1. Pendekatan Pragmatis, yakni dengan melakukan kegiatan konkret dan langsung untuk menumbuhkan perekonomian dalam masyarakat muslim di seluruh dunia terutama dengan membentuk sistem kelembagan yang dapat berfungsi mengembangkan perekonomian, sesuai dengan Islam.

2. Pendekatan Resitatif, yaitu dengan merumuskan berbagai kode etik ekonomi yang dapat ditarik dari al-Qur'an dan al-Sunnah terutama yang telah dirumuskan dalam kitab-kitab fiqh.

3. Pendekatan Rasionalitis-idealistis, yang menghasilkan rumusan tentang konsep rasionalitas ekonomi menurut ajaran Islam. Dari sini dapat dikembangkan berbagai teori dan model-model ekonomi yang bersifat ekonometris dengan dukungan data-data empiris.

4. Pendekatan Adaptif. Sebuah pendekatan yang mencoba mengkaitkan antara ajaran-ajaran Islam di bidang etika ekonomi dengan doktrin-doktrin atau ideologi Barat yang sudah ada seperti liberalisme dan berbagai ideologi sintesis atau ekletis yang berkembang akhir-akhir ini. $^{66}$

Pendekatan-pendekatan ini cukup mewakili variasi pendekatan yang digunakan sarjanasarjana muslim dalam menggagas ekonomi Islam. Tapi pendekatan ini hanya sebatas digali dari kenyatan empirik-epistemologi-empiris. Nienhaus menjelaskan, pendekatan rasionalistisidealistis adalah sebuah pendekatan yang utopis. Ini juga pendapat yang dipegang oleh Dawam Rahardjo. ${ }^{67}$ Tapi sebagian sarjana muslim yang belum ter-Barat-kan dan masih murni memegang ajaran Islam, menyatakan bahwa Islam sebagai agama yang mengandung pranata sosial sistem

pabrik itu bisa tinggal menjadi 4 atau lima saja, sementara pabrik yang lain bisa dimusnahkan. Dengan teori ini Marx ingin mengungkapkan bahwa krisis akibat persaingan bebas, akan menghasilkan jumlah kapitalis akan berkurang, sedangkan jumlah pekerja akan berkurang. Lebih lanjut, lihat penjelasan mengenai Law of Capital Accumulation.

66 Volker Nienhaus, "Islamic Economics, Policy Between Pragmatism and Utopia, dimuat dalam Economics, West Germany: Institutefor Scientific Cooperation, vol.25, 1982, h. 87- 88.

${ }^{67}$ M. Dawam Rahardjo, Etika Ekonomi dan Manajemen, Yogyakarta: Tiara Wacana, 1990. 
kehidupan (way of life atau nizham al-hayah) memiliki sistem perekonomian khas Islam (nizham al-iqtishad fi al-Islam) yang berbeda dengan sistem ekonomi lainnya ${ }^{68}$.

Para pemikir ilmu sosial beranggapan bahwa kode etik universal yang mendasari ekonomi modern adalah utilitarianisme, khususnya ajaran dari Jeremy Bentham. ${ }^{69}$ Dengan demikian upayanya adalah melakukan islamisasi pada ilmu dan sistem ekonominya. Tapi pendapat Jeremy Bentham tidaklah sepenuhnya dibenarkan, terutama menurut Syaikh Nabhani yang tatkala menggagas sistem ekonomi Islam menyatakan tentang perlunya membedakan antara ilmu ekonomi -- yang sebagian besarnya adalah bebas nilai -- dengan sistem ekonomi. Ilmu ekonomi membahas hal-hal yang berkaitan dengan peningkatan produksi, kualitas, dan kinerja. Kebanyakan ilmu-ilmu semacam ini bebas nilai dan bersifat universal. Contohnya, ilmu akuntansi, ia adalah ilmu yang bebas nilai dan tidak terpengaruh oleh pandangan hidup tertentu. Sedangkan sistem ekonomi sudah melibatkan tata nilai tertentu, misalnya; ideologi, pandangan hidup, norma dan etika. Hal-hal yang berhubungan dengan sistem distribusi barang dan jasa merupakan bagian dari sistem ekonomi. Islam melarang menimbun barang, dan beredarnya riba di tengah aktivitas ekonomi. Pandangan semacam ini berbeda dengan pandangan sistem ekonomi kapitalime dan sosialisme. Karena itu, islamisasi ilmu harus diarahkan pula kepada reformasi sistem ekonomi yang tidak bebas nilai tadi, dan diganti dengan sistem dan nilai-nilai yang Islami. $^{70}$

Menurut ahli ekonomi neo-klasik, Lord Robbins, ${ }^{71}$ ilmu ekonomi adalah, "Suatu ilmu yang mempelajari perilaku manusia sebagai hubungan antara berbagai tujuan dan alat-alat (untuk mencapai tujuan) yang langka adanya dan karena itu mengandung alternatif dalam penggunannya, maka tujuan maupun cara-cara penggunan alat-alat tersebut untuk mencapai suatu tujuan harus disesuaikan dengan syari'at Islam sebagai suatu cara dan pandangan hidup. Kegiatan ekonomi menurut pandangan Islam tidak diatur oleh keinginan-keinginan dan pengalaman manusia saja, Tuhan melalui wahyu-Nya telah memberikan pedoman yang kemudian dirumuskan oleh para 'ulama' menjadi syari'at. Kegiatan ekonomi apapun harus disandarkan kepada wahyu yang tercantum dalam Al-Qur'an dan al-Sunnah. ${ }^{72}$

Kini terlihatlah kontradiksi antara sistem ekonomi Islam dengan konsep ekonomi lainnya, terutama kapitalisme dan sosialisme. Kontradiksi ini semakin menyakinkan bila disitir pendapat salah seorang ekonom, Bocke, yang menyatakan bahwa nilai-nilai yang dianut oleh orangorang Timur seperti Indonesia tidak cocok bagi dan untuk mendukung perkembangan ekonomi

68 'Abd al-Rahman al-Malikiy, Al-Siyasaat al-Iqtishad al-Mitsla, Dr.Husain 'Abdullah, Dirasaat fi al-Fikr alIslamiy, Samih 'Athif al-Zain, Al-Islam Khuthutun 'Aridhah: Al-Iqtishad, Al-Hukm, al-Ijtima', [Islam, Garis-garis Besar Tentang: Ekonomi, Pemerintahan, dan Masyarakat].

${ }^{69}$ Mark A.Lutz \& Kenneth Lux, The Ch.lange of Humanistic Economics, California: The Benjamin Cummings Publishing.Co.Inc, Menlo Park, 1979, h.32-33. Paham Bentham ini sampai pada perumusan yang berkaitan dengan ilmu ekonomi, antara lain telah disempurnakan oleh John Stuart Mills, yang merumuskan arti utilitas sebagai kebahagian untuk sebanyak-banyak orang.

${ }^{70}$ Nabhani, Nizham al-Iqtishod, Beirut: tpn., 1953.

71 Definisi ini dikemukakan pertama kali oleh Lord Robbins dalam bukunya, "Essay on The Nature and Significance of Economics Science", London: MacMilland \& Co.LTD, 1962. Baca chapter I ("The Subject Matter of Economics") dan chapter II ("Ends and Menas").

72 Pengertian ini dikemukakan oleh S.M. Hazanus Zaman, dalam artikelnya, "Definition of Islamic Economics", Journal of Research in Islamic Economics, vol.1 noi.2 , 1984, h. 51 
pola Barat yang kapitalis. ${ }^{73}$ Demikianlah, ajaran moral yang berbeda akan menghasilkan pola perkembangan ekonomi yang berbeda pula. Hal ini merupakan perkara lumrah, sebab, setiap agama besar pasti memliki pandangan dasar mengenai manusia, secara eksplisit atau implisit. ${ }^{74}$ Ini adalah bukti nyata ketidakmungkinan membangun ekonomi syari'at di atas sistem ekonomi yang bercorak kapitalistik.

Dalam khazanah Islam klasik, Imam al-Ghazali merupakan pelopor dalam pembahasan ekonomi, dikaitkan dengan politik negara. Dalam bukunya Ihya' 'Ulum al-Diin, juz II, dalam pokok persoalan "Halal dan Haram", al-Ghazali telah meformulakan apa yang disebut oleh ekonomi modern sebagai konsep kepemilikan (property). Dia mengupas apa yang disebut dengan state property dalam pasal VII. Pada persoalan etika ekonomi, Al-Ghazali menekankan untuk bersikap zuhud; dianjurkannya agar 'ulama' bersikap non-kooperatif dengan penguasa. Misalnya, 'ulama' dilarang menerima pemberian dari negara. ${ }^{75}$

Selain membicarakan masalah-masalah ekonomi secara umum, Al-Ghazali juga memusaatkan perhatiannya pada soal keuangan negara, pemasukan dan pengeluarannya (aldukhul wa al-mashraf/rekapitulasi), yakni hukum menerima uang dari negara, serta hubungan ekonomi rakyat dengan pemerintah. Semua ini dituangkan dalam "Halal dan Haram", yang termaktub dalam 7 pasal dalam buku Ihya' 'Uluum al-Diin. ${ }^{76}$ Dalam hal pemasukan uang negara, disebutkan ada 8 sumber pemasukan; (1) jizyah dan kharaj, (2) harta warisan, (3) harta waqaf, (4) perusahan dan perkebunan negara, (5) perdagangan negara, (6) penghasilan-penghasilan karena hukuman, (7) Penetapan-penetapan terhadap pedagang, (8) Simpanan-simpanan perbendaharan negara (bait al-mal). ${ }^{77}$

Dalam bukunya Al-Mustashfa, al-Ghazali menambahkan, "Apabila pemerintah tidak mempunyai uang, dan kas negara tidak cukup untuk menggaji Angkatan Perang, sedangkan negara dalam keadan bahaya karena dikuatirkan musuh datang menyerbu dari luar, atau terjadi pemberontakan di dalam negeri dari pihak orang pengacau, maka Imam (Kepala Negara) boleh menetapkan atas orang-orang yang mampu untuk menutup pertahanan negara. $^{78}$

Formulasi Islam untuk sistem dan ilmu ekonomi, secara sistematis-praktis telah dituangkan dalam banyak kitab fiqh terutama dalam bab mu'amalah. ${ }^{79}$ Sistem kehidupan apapun --termasuk di dalamnya ekonomi-selalu dibangun di atas pandangan hidup tertentu tentang kehidupan. Sistem sosial Islam didasari oleh sebuah pandangan bahwa, manusia harus tunduk dan pasrah terhadap ketentuan-ketentuan profan dari Tuhan, yang tertuang di dalam Al-Quran dan al-Sunnah. Dalam kitab-kitab fiqh terdapat sub-sub pembahasan yang berhubungan dengan hudud, jinayat, mu'amalah, dan lain-lain. Sub-sub ini telah menunjukkan bahwa, Islam, dalam bentuk praktis

73 J.H.Boeke, Economics and Economics Policy of Dual Societies, Harlem: H.D. Tjeeuk Willink, 1951.

${ }^{74}$ Mohammad Iqbal, Islam Sebagai Suatu Cita Moral dan Politik, Bandung: Pt. Ma'arif, 1981,.

75 Al-Ghazali, Ihya' 'Uluum al-Diin, Juz.II, h.134

76 Ibid.

77 Ibid.

78 Al-Ghazali, Al-Mustashfa, juz I, h.203-204; Bandingkan Al-Imam al-Hafidz Abi Ubaid, Kitab al-Amwal, pada bab Haq al-Imam 'ala al-Ra'iyyah, wa Haq al-Ra'iyyah 'ala al-Imam [Hak Pemimpin atas Rakyat, dan Hak Rakyat atas Pemimpin], h.10.

${ }^{79}$ Imam Syafi'iy, al-Umm. Ibnu Hajar, Fath al-Bariy [kitab hadits yang disusun dalam pembahasan fiqh], Imam Syaukani, Nail al-Authar, dll. 
telah dituangkan dalam ajaran-ajaran yang bersifat praktis. Imam empat madzhab, serta imamimam lain pun telah menyusun pokok-pokok perincian, kaedah-kaedah, postulat-postulat, serta hukum-hukum praktis berkaitan dengan praktek-praktek kehidupan masyarakat. ${ }^{80}$ Meskipun upaya untuk merasionalkan --merumuskan teori-teori ekonomi Islam- belum dilakukan oleh pemikir Islam klasik, tapi karangan-karangan mereka sedikit banyak telah memberikan gambaran praktis dan aplikatif perilaku ekonomi Islam ${ }^{81}$.

Upaya untuk menempatkan Islam dalam konteks sistem ekonomi dan ekonomi terapan, serta komparasi sistem ekonomi Islam dengan sistem ekonomi kapitalis dan sosialis dilakukan dengan cemerlang oleh Dr.Abdurrahman al-Malikiy, dan Qadli Nabhani dalam buku Siyasaat alIqtishad al-Mitsla, dan Nizham al-Iqtishad fi al-Islam. ${ }^{82}$ Bahkan, keduanya telah berhasil membahasakan kembali sistem ekonomi dengan bahasa kontemporer, serta sisi unggul sistem ekonomi Islam atas sistem ekonomi lainnya. Keduanya tidak hanya membandingkan sistemsistem ekonomi tersebut, dari sisi praktis empiris, tapi, lebih dari itu, keduanya juga menghadirkan secara filosofis dan paradigmatis-teoritis, pandangan dasar, serta hukum-hukum yang menyertai sistem ekonomi tersebut. ${ }^{83}$ Sejauh ini, kedua pakar tersebut, cukup berhasil meletakkan konsep dasar ekonomi Islam, ${ }^{84}$ kemudian menuangkannya dalam sistem ekonomi (economic system).

Dalam pandangan Islam ekonomi ditegakkan untuk mewujudkan sebesar-besarnya kesejahteraan manusia, bukan untuk kesejahteraan individu-individu tertentu, atau individuindividu yang tidak terikat dengan norma dan etika Islam. Dengan kata lain, ekonomi dalam perspektif Islam diperuntukkan bagi seluruh manusia dan masyarakat bukan bagi individu dan kelompok masyarakat tertentu. Islam tidak memisahkan antara apa yang wajib ada bagi masyarakat dengan upaya mewujudkan kesejahteraan manusia, bahkan menjadikan dua hal tersebut saling berhubungan dan berkaitan satu dengan yang lain. Islam memperhatikan kepentingan individu dan masyarakat secara bersamaan. ${ }^{85}$

Menurut Dr Husain 'Abdullah dalam bukunya Dirasaat fi al-Fikr al-Islamiy, sistem ekonomi dalam Islam ditegakkan di atas tiga asas utama, Pertama, konsep kepemilikan (al milkiyah); Kedua, pemanfaatan kepemilikan (al-tasharuf fil al-milkiyah), Ketiga, distribusi kekayaan di antara masyarakat (tauzi'u al-tsarwah bayna al-naas). Masing-masing akan diuraikan secara rinci sebagai berikut:

${ }^{80}$ Lihat misalnya Al-umm, karya al-Syaifi'i, Al-muwatha' (kumpulan hadits hukum), oleh Imam Malik, Almuwafaqat, Bidayatul Mujtahid, Fiqh Sunnah, dan lain-lain. Ciri kajian ekonomi Islam klasik, adalah bersifat praksis, sehingga pembahasan dalam tataran-tataran paradigma-sistemis jarang sekali disinggung oleh 'ulama'-ulama madzhab klasik.

${ }^{\mathbf{8 1}}$ Ilmu ekonomi dalam Islam disebut dengan istilah "iqtishad", sedangkan para pelaku ekonomi dinamakan dengan "muqtashid". Tentang needs, Al-Ghazali membahas bahwa kebutuhan manusialah yang mendorong lahirnya perilaku ekonomi dan perkembangan ilmu dan sistem ekonomi. Lihat dalam Ihya' 'Ulumu al-diin, Al-ghazali. Sedangkan dalam hal etika, Al-Ghazali mengarang kitab berjudul, Adab al-Kasbi wa al-Ma'asyi. Begitu pula Al-Farabi, Ibnu Rusyd telah menyumbangkan pemikiran ekonomi yang dikaitkan dengan politik negara.

82 'Abd al-Rahman al-Malikiy, al-Siyasaat al-Iqtishad al-Mitsla, 1963.

83 Ibid.

${ }^{84}$ Pembahasan senada dilakukan oleh Dr. Mohammad Husein Abdullah, dalam kitab Dirasatu fi Al-fikriy alIslamiy, Darul Bayariq, Beirut, 1991, pada bab Usus al-Nizham al-Iqtishad fi al-Islam, (Asas-asas Sistem Perekonomian Islam).

${ }^{85}$ Samih 'Athif Az-Zain dalam kitab Al Islam Khuthutun 'Aridhah: Al Iqtishad, Al Hukm, al-Ijtima', [Islam; Garisgaris Besar Tentang: Ekonomi, Pemerintahan, dan Masyarakat], ttp., tpn., tth. 


\section{Konsep Kepemilikan (Al-Milkiyah)}

Islam memiliki pandangan yang khas tentang harta. Bahwa harta pada hakekatnya adalah milik Allah (QS al-Nur/24: 33). Harta yang dimiliki manusia, sesungguhnya merupakan pemberian dari Allah (QS al-Hadid/57: 7). Kata rizq artinya pemberian ('atha'). Atas dasar ini, kepemilikan atas suatu barang - yang artinya ada proses perpindahan kepemilikan — harus selalu didasarkan pada aturan-aturan Allah swt. Seseorang tatkala hendak memiliki sepeda motor, maka cara untuk mendapatkan 'kepemilikan' sepeda motor tersebut harus didasarkan pada aturan-aturan Allah swt, misalnya, dengan membeli, atau diberi hadiah, atau dengan caracara lain yang dibenarkan oleh hukum Islam.

Islam memiliki pandangan khas tentang harta, yang sama sekali berbeda dengan kapitalisme, yang tidak mengatur kuantitas (jumlah) dan kualitas (cara) perolehan harta serta pemanfaatannya. Islam juga berbeda dengan sosialisme yang mengatur baik kuantitas maupun kualitas harta. Dalam hal kepemilikan terhadap harta, Islam tidak mengenal kebebasan sebagaimana sistem kapitalisme -- dan pembatasan secara mutlak - sebagaimana sistem sosialisme. Islam hanya mengatur cara memiliki barang dan jasa serta cara pemanfaatan pemilikan tersebut. Kepemilikan adalah izin dari Syaari' (Allah) untuk menguasai dzat dan manfaat suatu benda. Menurut Dr Husain 'Abdullah, kepemilikan (milkiyyah) dibagi menjadi tiga macam, (1) pemilikan individu (milkiyah fardiyah), (2) pemilikan umum (milkiyah 'amah) dan (3) pemilikan negara (milkiyah daulah).

\section{a. Kepemilikan Individu}

Pemilikan individu adalah izin Syaari' kepada individu untuk memanfaatkan barang dan jasa. Adapun sebab-sebab pemilikan (asbabu al-tamalluk) individu, secara umum ada lima macam: 1) Bekerja (al 'amal), 2) Warisan (al-irts), 3) Kebutuhan harta untuk mempertahankan hidup, 4) Pemberian negara (i'thau al-daulah) dari hartanya untuk kesejahteraan rakyat berupa tanah pertanian, barang dan uang modal, 5) Harta yang diperoleh individu tanpa harus bekerja.

Harta dapat diperoleh melalui bekerja, mencakup upaya menghidupkan tanah mati (ihyau al-mawat), mencari bahan tambang, berburu, pialang, kerjasama mudharabah, musyaqah, bekerja sebagai pegawai. Sedang harta yang diperoleh tanpa adanya curahan daya dan upaya mencakup, hibah, hadiah, wasiat; diyat; mahar; barang temuan; "santunan" untuk khalifah atau pemegang kekuasaan pemerintahan.

Islam melarang seorang muslim memperoleh barang dan jasa dengan cara yang tidak diridhai Allah, seperti judi, riba, pelacuran dan perbuatan maksiyat lain -walaupun seakanakan tidak merugikan orang lain. Islam juga melarang seorang muslim untuk mendapatkan harta melalui cara korupsi, mencuri, menipu -sebab, hal ini pasti merugikan orang lain dan menimbulkan kekacauan di tengah-tengah masyarakat.

\section{b. Kepemilikan Umum}


Pemilikan Umum adalah izin dari Syaari' (Allah)' kepada masyarakat secara bersama untuk memanfaatkan barang dan jasa. Semisal, memanfaatkan; 1) Fasilitas umum, yaitu barang-barang yang mutlak diperlukan manusia dalam kehidupan sehari-hari seperti air, api --bahan bakar, listrik, gas), padang rumput (hasil hutan); 2) Barang barang yang tabiat kepemilikannya menghalangi adanya penguasaan individu seperti: sungai, danau, jalan, lautan, udara, masjid dan sebagainya; dan 3) Barang tambang dalam jumlah besar yang sangat dibutuhkan oleh masyarakat, seperti emas, perak, minyak dan sebagainya.

Pengelolaan terhadap kepemilikan umum pada prinsipnya dilakukan oleh negara, sedangkan dari sisi pemanfaatannya bisa dinikmati oleh masyarakat umum. Masyarakat umum bisa secara langsung memanfaatkan sekaligus mengelola barang-barang 'umum' tadi, jika barang-barang tersebut bisa diperoleh dengan mudah tanpa harus mengeluarkan dana yang besar seperti, pemanfaatan air di sungai atau sumur, mengembalakan ternak di padang penggembalaan dsb. Sedangkan jika pemanfaataanya membutuhkan explorasi dan eksploitasi yang sulit, pengelolaan milik umum ini dilakukan hanya oleh negara untuk seluruh rakyat dengan cara diberikan cuma-cuma atau dengan harga murah. Dengan cara ini rakyat dapat memperoleh beberapa kebutuhan pokoknya dengan murah.

\section{c. Kepemilikan Negara}

Kepemilikan negara adalah izin dari Syaari' atas setiap harta yang hak pemanfaatannya berada di tangan negara. Misalnya harta ghanimah, fa'i, khumus, kharaj, jizyah 1/5 harta rikaz, ushr, harta orang murtad, harta orang yang tidak memiliki ahli waris, dan tanah hak milik negara. Milik negara digunakan untuk berbagai keperluan yang menjadi kewajiban negara seperti menggaji pegawai, keperluan jihad dan sebgainya.

\section{Pemanfaatan Kepemilikan (Al-Tasharruf al-Milkiyah)}

Pemanfaatan pemilikan adalah cara --sesuai hukum syara'-- seorang muslim memperlakukan harta miliknya. Pemanfaatan harta dibagi menjadi dua topik yang sangat penting, yakni (1) pengembangan harta (tanmiyat al-mal), dan (2) infaq harta (Infaq al-mal).

\section{a. Pengembangan Harta (Tanmiyat al-Mal)}

Pengembangan harta adalah upaya-upaya yang berhubungan dengan cara dan sarana yang dapat menumbuhkan pertambahan harta. Islam hanya mendorong pengembangan harta sebatas pada sektor riil saja; yakni sektor pertanian, industri dan perdagangan. Islam tidak mengatur secara teknis tentang budi daya tanaman; atau tentang teknik rekayasa industri; namun, Islam hanya mengatur pada aspek hukum tentang pengembangan harta.

Dalam sektor pertanian misalnya, Islam melarang seorang muslim menelantarkan tanahnya lebih dari tiga tahun, bolehnya seseorang memiliki tanah terlantar tersebut bila ia mengolahnya, larangan menyewakan tanah, musaqah, dan lain-lain.

Dalam bidang perdagangan, Islam telah mengatur hukum-hukum tentang syirkah dan jual beli. Demikian pula dalam hal perindustrian, Islam juga mengatur hukum produksi barang, manajemen dan jasa, semisal hukum perjanjian dan pengupahan. Islam melarang beberapa aktivitas-aktivitas pengembangan harta, misalnya, riba -- nashi'ah pada perbankan, 
dan riba fadhal pada pasar modal --, menimbun, monopoli, judi, penipuan dalam jual beli, jual beli barang haram dan sebagainya.

\section{b. Infaq Harta (Infaq al-Mal)}

Infaq harta adalah pemanfaatan harta dengan atau tanpa ada kompensasi atau perolehan balik. Berbeda dengan sistem kapitalisme, Islam mendorong ummatnya untuk menginfaqkan hartanya untuk kepentingan umat yang lain -terutama pihak yang sangat membutuhkan. Islam tidak hanya mendorong kaum muslim untuk memanfaatkan hartanya dengan kompensasi atau perolehan balik yang bersifat materi saja, tapi juga mendorong umatnya untuk memperhatikan dan menolong pihak-pihak yang membutuhkan, serta untuk kepentingan ibadah, misalnya zakat, nafkah anak dan istri, dorongan untuk memberi hadiah, hibah, sedekah kepada fakir miskin dan orang yang memerlukan (terlibat hutang, keperluan pengobatan, musibah); dan infaq untuk jihad fi sabilillah. Islam telah melarang umatnya untuk menggunakan hartanya pada hal-hal yang yang dilarang oleh hukum syara', seperti riswah (sogok), israf, tabdir, dan taraf (membeli barang atau jasa haram), serta mencela keras sikap bakhil.

\section{Konsep Distribusi Kekayaan (Tauzi'al-Tsarwah)}

Islam telah menetapkan sistem distribusi kekayaan diantara manusia dengan cara sebagai berikut;

\section{a. Mekanisme Pasar}

Mekanisme pasar adalah bagian terpenting dari konsep distribusi. Tapi mekanisme ini akan berjalan dengan alami dan otomatis jika konsep pemilikan dan konsep pemanfaatan harta berjalan sesuai dengan hukum Islam.

\section{b. Bentuk Transfer dan Subsidi}

Untuk menjamin keseimbangan ekonomi bagi pihak yang tidak mampu bergabung dalam mekanisme pasar -karena alasan-alasan tertentu seperti; cacat, ediot, dan sebagainya-, maka Islam menjamin kebutuhan mereka dengan berbagai cara sebagai berikut:

1). Wajibnya muzakki membayar zakat yang diberikan kepada mustahik, khususnya kalangan fakir miskin.

2). Setiap warga negara berhak memanfaatkan pemilikan umum. Negara boleh mengolah dan mendistribusikannya secara cuma-cuma atau dengan harga murah.

3). Pembagian harta negara seperti tanah, barang dan uang sebagai modal kepada yang memerlukan.

4). Pemberian harta waris kepada ahli waris.

5). Larangan menimbun emas dan perak walaupun dikeluarkan zakatnya.

\section{F. Penutup (Kesimpulan)}


Langkah utama untuk membangun ekonomi syari'ah adalah, meletakkan prinsip-prinsip dasar, tata nilai, dan sistem ekonomi Islam. Prinsip-prinsip dasar Islam meliputi pokok-pokok keyakinan yang tertuang dalam arkaan al-iimaan (rukun iman). Tata nilai Islam mencakup etikaetika Islam yang tercakup dalam pembahasan akhlaq Islam. Sedangkan sistem ekonomi Islam membahas konsep ekonomi perspektif Islam ditinjau baik dari sisi filosofisnya maupun aplikasinya.

Prinsip-prinsip dasar ('aqidah) Islam, harus ditempatkan sebagai bangunan dasar (pondasi) yang membangun seluruh sistem kehidupan Islam. Selain itu, ia adalah ruh (spirit) yang memberi nafas hidup bagi seluruh sistem kehidupan. 'Aqidah Islam harus dijadikan juga, sebagai prinsip dasar yang melandasi seluruh aktivitas negara, masyarakat, dan individu muslim. Spirit inilah, yang akan membentuk karakter khas bagi seluruh sistem Islam, termasuk di dalamnya sistem ekonomi Islam.

Tata nilai Islam atau etika Islam sebenarnya merupakan bagian tak terpisahkan dari hukum Islam. Etika Islam atau akhlaq Islam adalah seperangkat aturan yang mengatur hubungan seorang manusia dengan dirinya sendiri. Islam sebagai dien yang sempurna telah mendorong umatnya untuk memiliki etika (akhlaq) yang luhur dan mulia. Sifat jujur, amanah, rajin, altruis, ekonomis, dan sifat-sifat mulia lainnya (akhlaq kariimah) haruslah dimiliki seorang muslim tatkala melangsungkan aktivitas apapun, termasuk perilaku ekonominya.

Dengan sifat-sifat semacam ini, perilaku seorang muslim akan selalu terjaga, dan akan menghasilkan pola hubungan antar masyarakat yang harmonis, saling asih dan asuh. Tidak acuh satu dengan yang lain, lebih mementingkan kepentingan orang lain daripada kepentingan diri sendiri (altruis). Watak semacam ini akan mendorong secara optimal laju produksi barang dan jasa, serta menekan secara maksimal perilaku-perilaku ekonomi yang kontra produktif. Sifat jujur, suka bekerja keras, amanah, disiplin akan menghasilkan pola kerja atau pola produksi yang maksimal. Pemilik modal, buruh, pekerja, dan pegawai yang memiliki akhlaq karimah akan berproduksi dan bekerja secara maksimal. Sebaliknya, pekerja, buruh, yang tidak amanah akan menghasilkan kontra produktif dan tidak akan berproduksi secara optimal. Bahkan, orang-orang yang tidak memiliki akhlaq mulia, akan bertingkah laku yang menyebabkan tereliminasinya hasilhasil pembangunan. Misalnya, pemabuk dan koruptor akan berperilaku destruktif terhadap hasilhasil pembangunan, bahkan menyebabkan merosotnya produktivitas kerja.

$$
\phi-\mathbf{d r s}-\phi
$$




\section{DAFTAR PUSTAKA}

Abu 'Ubaid, al-Imam al-Hafidz, Kitab al-Amwal, pada bab Haq al-Imam 'ala al-Ra'iyyah, wa Haq al-Ra'iyyah 'ala al-Imam [Hak Pemimpin atas Rakyat, dan Hak Rakyat atas Pemimpin], tth.

Al-Malikiy, 'Abd al-Rahman, Dr., Al-Siyasaat al-Iqtishadiyyah al-Mitsla, ttp.: tpn.1963.

Aron, Raymond, The Industrial Society, Three Essays on Ideology and Development, New York: Fredick A. Prager Publisher, 1967.

Berger, Peter L., The Sacred Canopy, Elements of a Sociological of Religion, New York: Garden City Doubleday and Company Inc, 1969.

Boeke, J.H., Economics and Economics Policy of Dual Societies, H.D. Tjeeuk Willink, Harlem, 1951.

Bung Hatta, Kumpulan Pidato, Jakarta: Idayu, 1983.

Dawam Rahardjo, M., Prof., Dr., Etika Ekonomi dan Manajemen, Yogyakarta: Tiara Wacana, 1990.

Dr. Mohammad Iqbal, Islam Sebagai Suatu Cita Moral dan Politik, Bandung: Pt. Ma'arif, 1981.

Durand, Gilbert, On the Disfiguration of the Image of Man in the West, Eronos no.8 (1969).; Golgonooza Press, Ipswich, 1976).

E. Goldsmith, 'Deindustrialising Society', The Ecologist, jld..7, no.4 (Mei 1977).

Edward Weisband, ed. Poverty Amidst Plenty: World Political Economy and Distributive Justice", Boulder, CO: Westview, 1989.

Gunnar Myrdall, The Political Element in the Development of Economics Theory, A.Clarton Book, New York: Simon and Schuster, 1969.

Hazanus Zaman, S.M., dalam artikelnya, "Definition of Islamic Economics", Journal of Research in Islamic Economics, vol.1 noi.2, 1984.

Husaini, Waqar Ahmed, Dr., Islamic Environmental Systems Engineering, London: Macmillan Press Ltd, 1980.

Husein Abdullah, Mohammad, Dr., Dirasaat fi al-Fikriy al-Islamiy, Beirut: Darul Bayariq, 1991.

J.M. Keynes, The General of The Employment Interest and Money, Tokyo: Maruzen Co. 1957.

Jeffry A. Frieden \& David A. Lake, ed., International Political Economy Perspektives on Global Power and Wealth, New York: ST.Martin's, 1991. 
Karl Marx dan Friedrich Engels (1848), Manifesto Partai Komunis, Jakarta: Yayasan Pembaruan, Cet. III, 1959.

Kenneth E.Boulding, Beyond Economics, Essay on Society, Religion and Ethics, The University of Michigan, Ann Arbor, 1970.

Kuntowijoyo, Paradigma Islam, Interpretasi Untuk Aksi, Bandung: Penerbit Mizan, cet-vi, 1994.

Lord Robbins dalam bukunya, "Essay on The Nature and Significance of Economics Science", London: MacMilland \& Co. LTD, 1962.

Mark A. Lutz \& Kenneth Lux, The Ch.lange of Humanistic Economics, California: The Benjamin Cummings Publishing.Co.Inc,Menlo Park, 1979.

Marsh, Alfred, Principles of Economics, New York: The MacMillan Company, 1948.

Meadows, D., et al, The Limits to Growth, Potomac Associates, New York, 1972.

Mill, John Stuart, Principles of Political Economy, With Some of Their Application to Social Philosophy, Fairfield: August M. Kelley Publishers, 1977.

Mubyarto, Ekonomi Pancasila, Gagasan dan Kemungkinan, Jakarta: LP3S, cet-1, 1987.

Mubyarto, Kemakmuran Rakyat, Kesejahteran Rakyat dan Keadilan Sosial, dalam Dinamika Ekonomi dan Iptek dalam Pembangunan, $M$ Rusli Karim dan Fauzie Ridjal (editor), Yogyakarta: PT. Tiara Wacana, untuk Yayasan Hatta, disponsori oleh Friederich Ebert 'Stiffung --Perwakilan Indonesia. Cet.1, Maret 1992.

Myrdal, Against the Stream, Critical Essay on Economics, New York: Vintage Books, 1975.

Nabhani, al-Qiyadah al-Islamiyyah dalam Nizham al-Islam, Beirut: tpn., 1953.

-------------, Nizhamu al-Iqtishodiy, Beirut: tpn., 1953.

Nienhaus, Volker, "Islamic Economics, Policy Between Pragmatism and Utopia, dimuat dalam Economics, West Germany: Institutefor Scientific Cooperation, vol.25, 1982.

Qadli Nabhani, Nizham al-Iqtishad fi al-Islam (Sistem Ekonomi Dalam Islam), Beirut: Dar alUmmah, ed. IV, 1990. , al-Nidzam al-Islamiy fi al-Islam, ttp.: tpn., 1990.

Barry Jones, R.J., Respectives on Political Economy, London: Francis Pinter,1983.

Robert.L.Heilbroner, The Worldly Philosopheres, New York: A.Touchstone Book, 1970.

Samih 'Athif al-Zain, Al Islam Khuthutun 'Aridhah: Al Iqtishad, Al Hukm, al-Ijtima', [Islam, Garisgaris Besar Tentang: Ekonomi, Pemerintahan, dan Masyarakat]. Ttp.: tpn., th. 
Sardar, Ziauddin, The Future of Muslim Civilisaation, terj: Rahmani Astuti, Rekayasa Masa Depan Peradaban Muslim, Bandung: Mizan, th.

Schumpeter, "The Theory of Economic Development" (Diterjemahkan dari bahasa Jerman oleh Radves Opie, Cambridge, Los Angeles: Harvard University Press, 1980).

Smith, Adam, The Wealth of Nation, , New York: The Modern Library 1937.

Tobroni \& Syamsul Arifin, Islam Pluralisme Budaya dan Politik, Refleksi Teologi Untuk Aksi Dalam Keberagaman dan Pendidikan, cet-1, Yogyakarta: SIPRESS, 1994.

Tobroni dan Syamsul Arifin, Islam Pluralisme Budaya dan Politik, Refleksi Teologi Untuk Aksi Dalam Keberagaman dan Pendidikan, Yogyakarta: SIPRESS,1994.

Weber, Max, The Protestant Ethic and the Spirit of Capitalism, terjemahan Talcott Parsons, London: Unwin University Book, 1974.

White, Lynn, "The Historical Roots of Our Ecological Crisis", jld.155 (1967), h.1203, dan A.T. von Leeuwen, Christianity in World History, New York: Scribner, 1964.

$$
\phi-\mathrm{drs}-\phi
$$

